\title{
Microscopic analysis of propolis from Polish regions
}

\author{
Z Warakomska $1^{\star}$, W Maciejewicz 2
}

\author{
${ }^{1}$ Agricultural University, Department of Botany, Akademicka 15, 20950 Lublin; \\ 2 Medical Academy, Department of Inorganic and Analytical Chemistry, Staszica 62081 , Poland
}

(Received 5 October 1990; accepted 13 April 1992)

\begin{abstract}
Summary - Ten sediment samples isolated from propolis samples collected in Poland were examined under the microscope. The sediment was obtained by an extraction method which ensured preservation of plant tissue structure. Thus in addition to pollen, the secretory discs and other plant elements were identified in each sample of propolis sediments. These elements were found to be identical to those isolated from fresh Betula and Alnus leaves. The pollen contents differed in various propolis samples and reflected the flora of the region of origin. The presence of secretory discs in the propolis samples confirmed the hypothesis that bees collected oil and resinous substances from plant surfaces such as the leaves of Betula and Alnus.
\end{abstract}

propolis / extraction method / pollen analysis / secretory disc / Betula / Alnus

\section{INTRODUCTION}

According to Küstenmacher (1911) propolis is derived from the balmy portion of the pollen digested in the honey stomach of the bee. Another theory maintains that propolis is collected from the sticky bud surfaces of poplar, birch and chestnut trees. Rösch (1927), Cattorini (1963) and Marletto and Olivero (1981) described the manner in which bees collect propolis from poplar buds. The plant origir of propolis has been emphasized both by König (1985) and Crane (1988). In the literature reviewed by König (1985), the resinous excretions of the buds of poplar trees are mentioned as the main sources of propolis in Europe, South America, West Asia and North Africa. Trees of secondary importance include the birch, oak, alder, wil- low and hazel in Europe; the Acacia Karroo tree in South Africa; the grasstree Xanthorrhoea pressii and $X$ australis in Australia; and the buds and bark of Plumeria accuminata, $P$ acutifolia, Schinus terebinthifolius and Psidium guajava in Hawaii.

The presence of pollen in propolis has been reported by Junkunz (1932), who found Lupinus, Robinia and Onobrychis sativa pollen grains in the insoluble portion of propolis. Vanhaelen and Vanhaelen-Fastre (1979) presented microphotographs of propolis originating from different countries in the world, with pollen grains clearly visible in some of them. Ricciardelli d'Albore (1979) attempted to determine the geographical origin of propolis by characterizing propolis samples from different countries on 5 continents. To ob-

* Correspondence and reprints 
tain sediment, Ricciardelli d'Albore applied the Erdtman acetolysis method (1954) consisting of treating the material with acid and alkali. The sporopollenin contained in pollen grains was resistant to acid and alkali action, while the internal pollen content and cellulosic intine as well as other plant elements were disintegrated (Dyakowska, 1959). When subjected to acetolysis, pollen grains become empty and concave. Only exine, which is saturated by sporopollenin, remained undestroyed: because it is resistant to action by alkali and acids, the surface sculpture of pollen grains was preserved. Ricciardelli d'Albore (1979) determined the pollen of plants in sediments of propolis samples to be characteristic of the flora of particular countries, with allusion (in some cases) to the region in which the samples had been gathered. He also noticed that the colour of propolis was different in particular countries. The samples from regions with a temperate climate were pale brown to dark brown in colour and those from Australia and tropical zones were black. Finnish propolis was orange, and Cuban propolis was dark violet in colour. Ricciardelli d'Albore (1979) was of the opinion that the pollen in propolis sediment is derived from the surrounding flora. It enters the hive via various routes: through atmospheric dust or during the collection of nectar by pollencovered bees. Parts of pollen pellets or bee bread may also get into propolis in the hive.

The aim of our study was to characterize pollen grains and other components of propolis that are insoluble in water and organic solvents.

\section{MATERIALS AND METHODS}

A microscopic examination was carried out on sediments isolated from 10 propolis samples originating from 3 regions in Poland (Lublin,
Przemysl and Upper Silesia). The material was prepared for examination according to the method of Warakomska and Maciejewicz (1985). The resulting sediments were composed of the insoluble parts of propolis. The extraction was carried out with $96 \%$ ethanol in a $1: 5 \mathrm{w} / \mathrm{v}$ ratio (ie 5 $\mathrm{cm}^{3}$ of ethanol to $1 \mathrm{~g}$ of propolis). Particles of propolis longer than 1-2 $\mathrm{mm}$ were used. The mixture was shaken several times, then left to stand at room temperature. After 4 days the ethanol extract was filtered. In some cases, the extraction process was accelerated by adding alcohol in the ratio of $1: 20 \mathrm{w} / \mathrm{v}$, placing the material in a mechanical shaker for $5 \mathrm{~h}$ with the solvent changed twice. After separating the alcohol by filtration, the residue was treated with 10 vol benzene, shaken for $10 \mathrm{~min}$ (in a shaker) then centrifuged. The upper layers were carefully removed. The benzene extraction was repeated 5 times. The last 2 extractions were carried out at $50^{\circ} \mathrm{C}$. The sediment obtained was then extracted twice with $10 \mathrm{vol}$ acetone at $40^{\circ} \mathrm{C}$. The acetone extract was separated by filtration and the residual acetone evaporated. A $5 \% \mathrm{w} / \mathrm{v}$ suspension of the dried sediment in 1:1 mixture of glycerol and water was prepared. The addition of a few drops of $2 \% \mathrm{NaOH}$ caused a slight swelling of the pollen grains. The suspension was filtered through a strainer with $0.3-\mathrm{mm}$ holes to remove larger sediment fragments, then the suspension was placed between glass microscopic slides to obtain homogeneous smears. Each preparation contained over 300 pollen grains, a number considered by Dyakowska (1959) and Moar (1985) to be sufficiently representative for such examination. Pollen identity was determined for each preparation and the results interpreted by the method of Louveaux et al (1970).

\section{RESULTS AND DISCUSSION}

The results of extraction of 3 different propolis samples are given in table I. The dry residue of the ethanol extract (obtained after solvent evaporation) was 55.0-73.9\% of the weight of the propolis sample. Benzene + acetone extracted 17.6-31.6\% (mainly wax) and the sediment remaining after extraction covered $8.5-13.2 \%$. 
Table I. Percentage of fraction (dry residue weight) extracted from propolis by means of organic solvents.

\begin{tabular}{cccc}
$\begin{array}{c}\text { Sample } \\
\text { No }\end{array}$ & $\begin{array}{c}\text { Ethanolic } \\
\text { extr } \\
\text { of propolis } \\
(\%)\end{array}$ & $\begin{array}{c}\text { Benzene } \\
\text { +acetone } \\
\text { extr(wax) } \\
(\%)\end{array}$ & $\begin{array}{c}\text { Insoluble } \\
\text { sediment } \\
(\%)\end{array}$ \\
\hline & & & \\
1 & 73.9 & 17.6 & 8.5 \\
2 & 55.2 & 31.6 & 13.2 \\
3 & 64.2 & 27.0 & 8.8 \\
\hline
\end{tabular}

An example of analysis of a single sediment of propolis is presented in table II. The microscopic analysis showed the percentage of pollen grains in the sediment of propolis. The main components of the pollen and their abundance in 10 samples of propolis sediments are presented in tables III and IV. About $9-21 \%$ of pollen grains in the samples analyzed were extremely deformed and unrecognisable. The most abundant pollen identified was from plants of the family Cruciferae, mainly Brassica, Sinapis and Raphanus, which amounted to $9-33 \%$, Salix pollen was present in all samples: $6-16 \%$, as were lesser amount of pollen from Centaurea cyanus and Trifolium pratense. Small quantities of pollen from weeds, meadow and herbaceous plants and anemophilous trees were found in all preparations (Betula, Alnus, Populus, Urtica, Salix and Rumex). In addition, the sediment contained spores of parasitic fungi (Ustilago, Puccinia and Tilletia).

Leaf fragments of dicotyledonous plants which could be recognised by the presence of stomatal apparatus, skins with thick epithelium, plant hairs and calcium oxalate crystals in the form of druses were frequently found in the sediment.

It was quite surprising to find in all specimens the secretory discs such as those
Table II. Microscopic analysis of pollen in propolis sample No 4.

\begin{tabular}{lrr}
\hline & & \\
Pollen origin & & \\
& & \\
\hline & & \\
2 Sotal & \\
3 Pinus & 53 & 20.17 \\
4 Betula & 15.05 \\
5 Achillea type & 23 & 6.53 \\
6 Trifolium repens & 22 & 6.26 \\
7 Bellis & 19 & 5.39 \\
8 Gramineae & 13 & 3.69 \\
9 Populus & 10 & 2.85 \\
10 Sinapis & 10 & 2.85 \\
11 Centaurea cyanus & 10 & 2.85 \\
12 Helianthus & 9 & 2.55 \\
13 Taraxacum & 7 & 1.99 \\
14 Tilia & 7 & 1.99 \\
15 Anthriscus & 6 & 1.70 \\
16 Cirsium & 6 & 1.70 \\
17 Alnus & 5 & 1.43 \\
18 Fagopyrum & 5 & 1.43 \\
Macerated and unrecognized & 37 & 10.51 \\
& & \\
\hline
\end{tabular}

Below 1\%: Lamium, Malus/Prunus, Trifolium pratense, Artemisia, Juglans, Papaver, Plantago, Secale, Thymus, Acer pseudoplatanus, Corylus, Jacea type, Lotus, Melilotus, Phacelia, Rubus, Uimus, Juncus, Ranunculaceae, Kenuthia. In the sample examined, there were 334 pollen, 49 disc-like elements, some fragments of leaves and spores.

which occur on Betula and Alnus leaves. To identify these elements, microscope control preparations from fresh Betula and Alnus leaves were performed, then measured and drawn by means of a microscopic drawing device. The comparison of discs from propolis and control preparations is presented in figures 1-3. Similar multicellular discoid secreting hairs have been described by Hejnowicz (1980).

These hairs or discs, termed colleters, secrete a mixture of terpenes and mucus. The exudate accumulates in the subcuta- 
Table III. Percentage of pollen in 10 propolis samples.

\begin{tabular}{|c|c|c|c|c|c|c|c|c|c|c|}
\hline \multirow[t]{2}{*}{ Pollen } & \multirow{2}{*}{$\frac{A}{1}$} & \multicolumn{7}{|c|}{$B$} & \multicolumn{2}{|c|}{$c$} \\
\hline & & 2 & 3 & 4 & 5 & 6 & 7 & 8 & 9 & 10 \\
\hline Cruciferae & 33 & 27 & 23 & 9 & 22 & 38 & 22 & 23 & 14 & 16 \\
\hline Salix & 16 & 12 & 15 & 8 & 13 & 6 & 9 & 10 & 7 & 9 \\
\hline Centaurea cyanus & 6 & 7 & & & & & & & 13 & 13 \\
\hline Gramineae & & & & 10 & & & & & 6 & 10 \\
\hline Tilia & & & & & & & 11 & 11 & & \\
\hline Trifolium pratense & 6 & & & & & & & & & 6 \\
\hline Papaver & & 6 & & & & & & & & \\
\hline Pinus & & & 6 & & & & & & & \\
\hline Betula & & & 6 & & & & & & & \\
\hline Achillea type & & & 5 & & & & & & & \\
\hline Untica & & & & 10 & & & & & & \\
\hline Trifolium repens & & & & & 8 & & & & & \\
\hline Malus type & & & & & & & & 5 & & \\
\hline Fagopyrum & & & & & & & & & 10 & \\
\hline Macerated and unrecognisable & 14 & 18 & 10 & 15 & 14 & 15 & 21 & 18 & 13 & 9 \\
\hline Other origin pollen under $5 \%$ & 25 & 30 & 35 & 48 & 43 & 41 & 37 & 33 & 37 & 36 \\
\hline No of pollen grains examined & 411 & 349 & 383 & 334 & 352 & 377 & 363 & 369 & 402 & 389 \\
\hline No of secretory discs & 20 & 45 & 41 & 49 & 46 & 11 & 17 & 16 & 13 & 14 \\
\hline
\end{tabular}

A: Upper Silesia; B. Lublin district; C. Przemysl district.

Table IV. Prevalence of pollen grains in 10 propolis samples.

Pollen (\%)

Anthriscus type, Centaurea cyanus, Cruciferae, Malus / Prunus type,

Papaver a $^{\text {a Salix, Trifolium repens, Trifolium pratense, Gramineae a }}$

Achillea type, Artemisia a, Fagopyrum, Helianthus type, Pinus a, Taraxacum type, Tilia 90

Betula a, Cirsium type, Plantago a, Rubus type, Vicia 80

Aesculus, Alnus a, Corylus a, Melitotus $\quad 70$

Chenopodium a, Frangula alnus, Lotus, Secale a $\quad 60$

Caryophyllaceae, Populus a, Rumex a $\quad 50$

Acer pseudoplatanus, Fragaria hort, Majorana type, Ranunculus ${ }^{\text {a }}$, Urtica ${ }^{\text {a }}$

Aster type, Bellis a, Cannabis a, Juglans regia a, Jacea type, Quercus a, Vaccinium 30

Carpinus a, Chamaenerion, Comus, Filipendula a, Juncus a, Lamium type,
Myosotis, Partenocissus, Phacelia, Verbascum a, Zea mays a

$\begin{array}{ll}\text { Unidentified (16 species) } & 10\end{array}$

a plants without nectaries. 


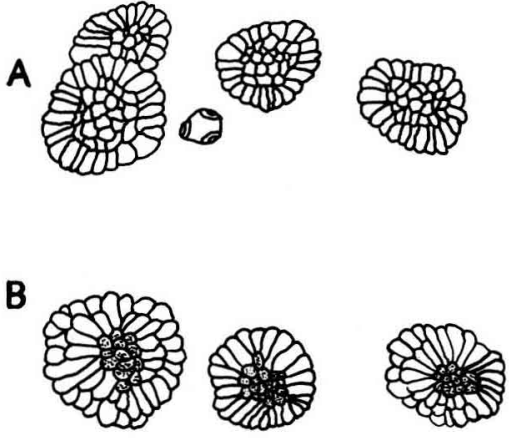

Fig 1. Secretory discs: A: from propolis sediment, Corylus avellana $L$ pollen close by; $B$ : from leaves of Betula verrucosa Ehrh. Discs $57.4-69.6 \mu \mathrm{m}$ in diameter.
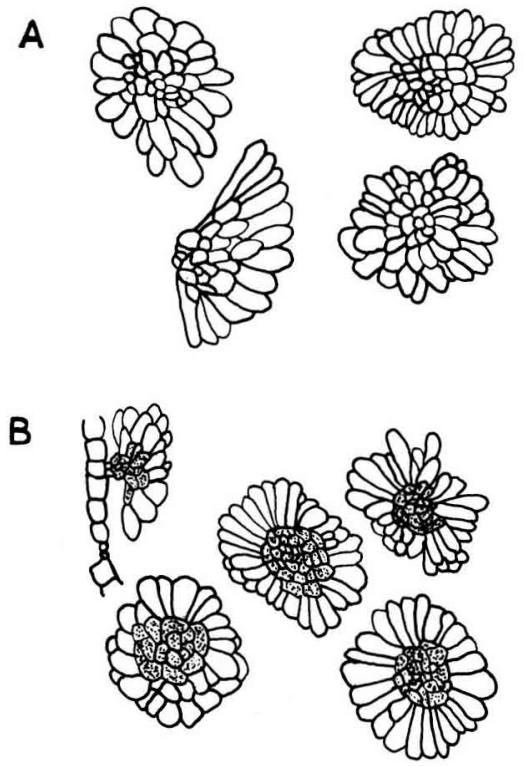

Fig 2. A: Alnus secretory discs from propolis sediment; B: Secretory discs from leaves of $A 1$ nus glutinosa (L) Gaertn. Discs 80-100 $\mu \mathrm{m}$.

neous cavity and once the latter is broken it pours out onto the leaf surface, making it sticky. Similar forms of secretion occur on bud scales and leaf germs of birch, alder
A
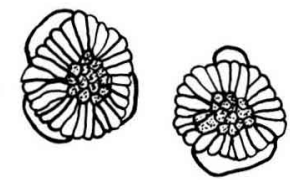

B
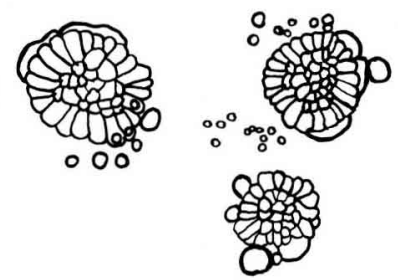

Fig 3. Secretory discs from leaves of Betula verrucosa Ehrh. A: oil flowing out; Sudan III redstained; B: emulsification of data following $\mathrm{NaOH}$ treatment.

and chestnut trees (fig 2). The only substances of birch secretory discs became characteristically red in fresh leaf preparations when treated with the fat reagent Sudan III, and underwent emulsification in $\mathrm{NaOH}$ (fig 3).

The smears revealed dark brown plant tissue fragments identical to the secretory glands found on Betula and Alnus leaves. The animal remains contained in the sediment were bee hairs, chitin particles with or without sensillae, Lepidoptera wing scales (perhaps wax moth) and small ants.

\section{CONCLUSION}

Acetolysis and homogenization leading to destruction of plant tissue elements used previously were replaced in the present study by an extraction method designed to obtain microscope preparations from propolis sediment. Owing to the extraction method of propolis used in the present research, parts of plants containing cellulosic 
walls were preserved in the sediment. The pollen was therefore less deformed. Resins and wax which were present in propolis were extracted by organic solvents. The tissue of plants was not damaged. The treated pollen was determined according to the recommendation of the International Committee for Bee Botany (Louveaux et al, 1970) currently used for the determination of pollen grains present in honey.

\section{ACKNOWLEDGMENTS}

The authors wish to thank E Soczewinski, head of the Department of Inorganic and Analytical Chemistry, for suggestions and for the critical reading of this manuscript.

\section{Résumé - Analyse microscopique de} propolis provenant de Pologne. On a effectué l'analyse microscopique de 10 échantillons de propolis provenant de Pologne. La méthode d'extraction utilisée, à base de solvants organiques, a permis d'isoler de la propolis des éléments végétaux insolubles tout en préservant la structure du tissu cellulaire des plantes. Avec la méthode de l'acétolyse, appliquée jusqu'à présent, on utilisait des acides et des bases concentrées qui dissolvaient la cellulose. La méthode pour obtenir le sédiment consiste en une extraction complète de la propolis à l'aide de solvants organiques : alcool éthylique à $96 \%$ (1:5 poids/ vol), puis toluène et finalement acétone. Après filtration et évaporation on obtient le sédiment sec. Les pourcentages des diverses fractions (éthanolique, benzénique + acétonique et sédiment insoluble) sont données dans le tableau I. Le sédiment a été dilué ( $5 \%$ poids/vol) dans un mélange $1: 1$ de glycérine et l'eau auquel on a ajouté quelques gouttes de $\mathrm{NaOH}$. La suspension a été filtrée avec un filtre de maille 0,3 $\mathrm{mm}$, puis on a montré les préparations entre lame et lamelle. Pour chaque préparation on a compté plus de 300 grains de pollen. Les résultats de l'analyse pollinique ont été interprétés selon Louveaux et al (1970). Le tableau II donne, à titre d'exemple, l'analyse pollinique d'un échantillon; le tableau III le pourcentage de pollen des 10 échantillons et le tableau IV la fréquence des divers pollens dans les 10 échantillons. Pour la première fois on a trouvé dans tous les échantillons des disques sécréteurs (figs 1A, 2A). Après comparaison avec des préparations faites à partir de feuilles fraîches de Betula verrucosa et d'Alnus glutinosa (figs $1 \mathrm{~B}, 2 \mathrm{~B}$ ), ces structures se sont révélées semblables à celles qui sont présentes sur les feuilles de Betula ou d'Alnus. Le spectre pollinique caractérise la flore environnante butinée et la période de récolte de la propolis. La présence de disques sécréteurs confirme l'origine végétale de la propolis.

Propolis / méthode d'extraction / analyse pollinique / disque sécréteur / Alnus / Betula

\section{Zusammenfassung - Mikroskopische} Analyse von Propolis aus Polen. Es wurden mikroskopische Analysen von Propolisproben aus Gebieten von Polen durchgeführt. Mit der angewandten Extraktionsmethode mit organischen Lösungsmitteln, war es möglich, wasserunlösliche Pflanzenelemente aus Propolis zu isolieren, wobei auch die Zellulosestrukturen erhalten blieben. Bei der bisher benutzten Methode der Azetolyse wurden konzentrierte Säuren und Laugen benutzt und Zellulose zerstört.

Die Extraktionsmethode zur Gewinnung von Sediment aus Propolis besteht in der vollständigen Extraktion mit den organi- 
schen Lösungsmitteln Äthyl- und Methylalkohol, dann mit Benzol oder Toluol und schließlich mit Azeton. Durch Zentrifugierung der letzten Azetonfraktion wurden feste Propolisbestandteile gewonnen. Für 3 Proben wird in Tabelle I die prozentuelle Zusammensetzung der Äthanol und der Benzol + Azetonfraktion und des aus Propolis isolierten Sediments angegeben. Das getrocknete Sediment wurde im Gewichtsverhältnis von $5 \%$ Propolis in einem Gemisch von Wasser und Glyzerin (1:1) mit Zusatz von einigen Tropfen $\mathrm{NaOH}$ suspendiert. Die Suspension wurde durch ein 0.3 $\mathrm{mm}$ Sieb gefiltert, um gröbere Partikel zu entfernen, und anschließend gleichmäßig auf einem Objektträger ausgebracht. In jedem mikroskopischen Präparat wurden über 300 Pollenkörner ausgezählt. Die Pollenkörner wurden bestimmt und die Ergebnisse nach Louveaux et al (1970) interpretiert. Ein Beispiel der quantitativen Pollenanalyse einer Einzelprobe wird in Tabelle II gegeben. Tabelle III gibt den Pollenprozentsatz von 10 Propolisproben wieder und Tabelle IV die Pollenfrequenz.

Außer Pollen wurden erstmalig in allen Proben scheibenförmige Sekretionshaare (Colleteren) gefunden, die identisch sind mit solchen, die auf der Blattfläche von Betula- und Alnus gefunden werden (Abb 1A, 2A). Dies konnte durch den Vergleich mit Kontrollpräparaten aus frischen Betulaund Alnus-blättern bestätigt werden ( $\mathrm{Abb}$ $1 B, 2 B)$. Außerden wurden in manchen Propolissedimenten Pilzsporen gefunden.

Das Pollenbild ist charakteristisch für die Flora der Trachtgegend und die Jahreszeit, in der Propolis gesammelt wurde. Die Sekretionsscheiben bestätigen die pflanzliche Herkunft der Propolis.

Propolis / Extraktionsmethode / Pollenanalyse / Sekretionshaare / Alnus / Betula

\section{REFERENCES}

Cattorini PE (1963) La api e glu uomini (Bees and men). Fitoterapie 34, 85-93

Crane E (1990) Beekeeping: Science, Practice and World Resources. Heineman, London

Dyakowska J (1959) Podrecznik Palynologii (Handbook of Palynology). Wyd Geolog, Warsaw

Erdtman G (1954) An Introduction to Pollen Analysis. Waltham, MA, USA

Hejnowicz Z (1980) Anatomia i Histogeneza Roslin Neczyniowych (Anatomy and Histogenesis of Vascular Plants). PWN, Warsaw Jungkunz B (1932) Bee's resin (propolis). Chem Umschau 39, 30-33

König B (1985) Plant sources of propolis. Bee World 66 (4), 136-139

Küstenmacher (1911) Propolis. Ber Dtsch Pharm Ges 21 (1), 65-92

Louveaux J, Maurizio A, Vovwohl G (1970) Les méthodes de la mélissopalynologie. Apidologie 1 (2), 211-227

Marletto F, Olivero G (1981) Ricerche su raccolta e utilizzazione della propoli da parte della api. Apic Mod 72 (4), 131-140

Moar NT (1985) Pollen analysis of New Zealand honey. N Z J Agric Res 28, 39-70

Ricciardelli d'Albore G (1979) L'origine géographique de la propolis. Apidologie 10 (3) 241267

Rösch GA (1927) Observations as propoliscollecting bees. Biol Zentralb/ 47 (2), 113 (in German)

Warakomska Z, Maciejewicz W (1985) Metoda analizy mikroskopowej propolisu (The method of microscopic analysis of propolis). In: XXI Naukowa Konf Pszczel (Sci Conf Beekeeping) 27-28 February 1985; Pulawy, Ref 34 (in Polish)

Vanhaelen M, Vanhaelen-Fastre R (1979) Propolis. Origine, micrographie, composition chimique et active thérapeutique. $J$ Pharm Bel $34(5), 253-259$ 